\title{
Using Cooperative Learning Model to Enhance Academic Performance of Teacher Trainees in Some Selected Topics in Integrated Science at Saint Monica's College Of Education
}

\author{
${ }^{1}$ Stephen Kwame Amoako, ${ }^{2}$ Kennedy Ameyaw Baah ${ }^{*}{ }^{3}$ Fidelis Kamaayi, \\ ${ }^{4}$ Samuel Sylvester Dapaah, ${ }^{5}$ Charles Amoah Agyei \\ ${ }^{1}$ Science Department, St. Monica's College of Education, Mampong-Ashanti \\ ${ }^{2}$ Science Department, Wesley College of Education, Kumasi \\ ${ }^{3}$ Science Department, Accra College of Education, Accra \\ ${ }^{4}$ Science Department, St. Joseph's College of Education, Bechem \\ ${ }^{5}$ Science Department, OLA College of Education, Cape Coast
}

\begin{abstract}
The study sought to investigate the effects of using cooperative learning on female teacher trainees of the Colleges of Education in learning some selected topics in Integrated Science. The investigation also sought to determine whether the Cooperative Learning Approach enhances the attitude and motivation of the trainees towards learning of Integrated Science. The study was carried out at the St. Monica's College of Education in the Mampong Municipality of the Ashanti Region. In all, 80 teacher trainees consisting of 40 each from control and experimental groups were purposively sampled to participate in the study. The teacher trainees in the experimental group were exposed to the Cooperative Learning Approach and the trainees in the control group were lectured during the period of the study. The results of the study showed that the cooperative learning strategy was very relevant and beneficial in helping the teacher trainees of the St. Monica's College of Education to improve on their performance in, and attitudes towards, the teaching and learning of Integrated Science. It was therefore recommended among other things that the science teachers should endeavour to integrate cooperative learning into their routine methods of instruction in the teaching and learning of Integrated Science.
\end{abstract}

Keywords: cooperative learning approach, purposive sampling, experimental group, college of education, motivation

\section{Introduction}

Education is generally considered as the keynote to national development in all societies. It is a lifelong process in which the innate abilities and talents of people, both young and old, are brought out and developed. It is the most potent force shaping peoples' knowledge, attitudes, perceptions, skills, and personalities (Antwi, 1992).

Education may also be recognised as the backbone of every economy. This is because it is concerned with the provision of the required labour force to take up positions in the labour front. Economic crisis and competition in the world market have brought to the fore the need for the application of scientific methods to maximise production. This has also thrown light on the need for research to improve such scientific methods as well as their implementation. The Government of Ghana, seeing the need for science and technology, deemed it fit to reform the hitherto arts-biased educational system, to include more scientific, technological, and vocational-biased courses. The aim is to raise the needed manpower to lead in the nation's technological advancement.

Singer (1964) noted that it is only where the working force at all levels is sufficiently literate, educated, trained, and mobile to take advantage of new advances in techniques and organisation of production that the creation of a built-in industry of progress becomes possible. It is also recognised that the socio-economic 
development of any country depends on a cadre of well-educated and well trained personnel produced especially through secondary and tertiary levels of education.

Researchers and writers in recent times have identified the multiple benefits that accrue to females, their families and the nation as a whole as these females delve into the scientific and technological world. Aggrey (1993) indicated that education and training make girls and women more creative, inventive and selfconfident. Participants in a conference on Education and Work Opportunities for Females in African Countries in Morocco in May 1971 noted that African women are an indispensable part of the human resource for national development. It was observed that apart from helping to raise the productivity levels of females so as to make them participate more effectively in the economic process, education provides other benefits to females such as making them acquire improved standards of health, nutrition and sanitation (UNESCO, 1986).

Women's unequal access to education thus constitutes a problem which needs to be solved if developing countries like Ghana would achieve any meaningful socio-economic development. This is because if females are to be able to contribute meaningfully to the socio-economic development of Ghana, then they should be gainfully employed.

In a report presented to UNESCO on Access of Girls and Women to Science and Vocational Education, Hallack (1990) remarked that since development in society requires of women, besides family and domestic activities for which training can be given a much wider participation in all types of occupation, the facilities for women and girls in science and vocation should be of the same importance and range as those offered to men. Men and women should have equal opportunity for science education. A special effort should be made in order to give women the possibility of personal fulfillment in science and vocational education.

However, almost after two decades after which this observation was made and despite the numerous benefits that education and training are known to provide females and the nation as a whole, women's unequal access to and participation in Science Education still remains a national problem. At the basic and the senior secondary schools, the teaching staff directly and indirectly encourages the male students to pursue science and technical courses like Physics, Chemistry, Technical Drawing and Metal Work while the female students are made to pursue courses like Home Economics, Catering, and Dressmaking. The teaching industry has very few female teachers handling science subjects.

The Government of Ghana and non-governmental organisations are making striding efforts to improve on the perception and the performance of females in science education through workshops, fora and other projects such as Science Technology and Mathematics Education (STME) clinics for girls, access course for women to gain admission into Colleges of Education to pursue science as well as the institution of scholarship schemes for girls, yet the performance of these female trainees in science at St. Monica's College of Education is not encouraging. In the Colleges of Education such as St. Monica's College of Education where the trainees are all females, it is interesting to note that only one of the teachers handling science subjects is female who serves as a sole role model to encourage the female trainees to pick up the challenge. For this reason, the researcher investigated how cooperative learning model can be employed to enhance academic performance of teacher trainees in some selected topics in integrated science.

\section{Statement of the Problem}

A series of observations made during Integrated Science lessons taught by some of the science teachers in St. Monica's College of Education revealed that trainees' participation in the lessons were not encouraging. Most trainees provided wrong answers to the questions asked. Besides, the scores recorded from the trainees' exercise books were not impressive. Majority of the trainees scored between 30 and 50\% in class exercises and 10 to $50 \%$ in end of semester mock examinations. Again, the performance of teacher trainees in the end of semester examination as reported in the Chief Examiners report (Institute of Education, 2005; $2006 ; 2007$; 2008; 2009; 2010) indicated that a large proportion of the trainees performed poorly in Integrated Science of which St. Monica's College of Education, Mampong-Ashanti was no exception.

The Chief Examiner's reports for Integrated Science for the DBE (Diploma in Basic Education) programme, 2007 specifically indicated that $82 \%$ was the highest score in Integrated Science and as many as 273 trainees scored below $10 \%$. This unfortunate situation could be due to the fact that the aims/objectives of learning, which the curriculum set to attained, such as improved scientific thinking and understanding and problem- 
solving skills or experiences of the trainees were not properly enhanced at the implementation stage, which is due to the learning culture of science in schools in Ghana.

In addition, because the lecture method dominates teaching at St. Monica's College of Education, trainees are denied the science that helps them most in solving everyday personal problems. Trainees are also denied relevant science that is most fun and interesting, and many of them think of science as a body of knowledge that is difficult to understand. Many science tutors teach knowledge only and pay little or no attention to the means by which it was discovered. Teachers often teach only a portion of science and neglect the part that helps them most if they are to become functional scientist.

According to Shaughnessy (1992), cooperative learning promotes critical skills, improves classroom results, involves students actively in the learning process, and models appropriate student problem solving techniques. Therefore, a study aimed at improving the performance of teaching and learning of Integrated Science of trainees of St. Monica's College of Education through the cooperative method appeared to be warranted.

\section{Purpose of the Study}

The study was intended to find out whether cooperative learning can improve trainee teachers' performance in selected topics (photosynthesis, digestion, reproduction, IUPAC nomenclature, balancing of chemical equations, chemical bonding, mole concept, and measurement) in Integrated Science. It also sought to find out whether cooperative learning has an effect on trainee teachers' content knowledge in Integrated Science and can motivate and improve the trainee teachers' performance in Integrated Science. The study was also aimed at assessing the impact of the cooperative learning; evaluate the outcome of the intervention as a whole and to make recommendations to the appropriate authorities based on the findings of the study.

\section{Research Question}

The following research question was formulated to guide the study:

Is there significant difference between the mean scores of the teacher trainees of St. Monica's College of Education taught Integrated Science using Cooperative Learning Approach and the teacher trainees taught using the lecture method?

\section{Methodology}

The research design used in this study was action research. The target population was all the female trainees in all the Colleges of Education in Ghana. However, the accessible population was composed of all the female trainees pursuing the Diploma in Basic Education (DBE) programme at various levels at St. Monica's College of Education, which is a women's college found in Asante Mampong in the Ashanti Region.

The entire trainees of St. Monica's College of Education were stratified into two major groups; namely the continuing trainees who attended lessons in the morning and afternoon sessions and the out programme trainees who were having their teaching practice at their various stations. Purposive sampling was employed to select the trainees from the first year group. This is because the problem was identified among the first year trainees. The purposive sampling technique did not leave out any subject exposed to the same treatment for the effective change expected to take place in the class.

The problem under study was typically identified at the DBE Form One 'C' class of the St. Monica's College of Education. The class supposedly consisted of trainees who were at the 'bottom' in terms of academic performance, considering all the year groups' academic performances. Two intact forms (1C and $1 \mathrm{E}$ classes) of the first year group were involved in the study. The $1 \mathrm{C}$ class was used as the experimental group and $1 \mathrm{E}$ class was used as the control group. This is because the mean score of the trainees from the $1 \mathrm{E}$ class (control group) was higher than the mean score of the trainees from the $1 \mathrm{C}$ class (experimental group) in the pretest. The trainees in $1 \mathrm{C}$ class were further put into 10 groups of four each. The purpose was to ensure maximum participation and interactions among group members involved in the study. In all 80 trainees comprising 40 trainees respectively in $1 \mathrm{C}$ and $1 \mathrm{E}$ classes were involved in the study.

The instrument used for collecting data for the study for both the pre-intervention and the post intervention was a combination of semi-structured questionnaire and an achievement test. The test items used for the pretest were sampled from the set of past examination questions since the inception of the Diploma in Basic 
Education programme on Integrated Science 1 from 2005 to 2010 in the Colleges of Education. The topics were photosynthesis, digestion, reproduction, IUPAC nomenclature, balancing of chemical equations, chemical bonding, mole concept, and measurement. The 10 pre-test items covered the cognitive, affective and psychomotor domains. The purpose was to reveal the kind of thinking and understanding the trainee teachers had in learning and teaching Integrated Science at the basic school level. The post-test items were similar to the pretest items and therefore could be said to be of the same difficulty indices. Both tests were administered within duration of 30 minutes. This helped in the analysis of both stages of intervention of the study in order to make a comparison between them.

A semi-structured questionnaire was developed for the trainees to ascertain their impression about the teaching and learning of Integrated Science after the cooperative learning approach (CLA) has been adopted for the intervention. The questionnaire consisted of 10 items and the trainees were required to tick one of its corresponding responses according to their knowledge and perception and six other items, which required the trainees to provide their own responses. The questionnaire was used for the reason that it is easy for collecting data and trainees may not fear of being victimised as in an interview. It gave the trainees opportunity to express whatever idea they had. It also offered trainees complete anonymity. The trainees had enough time to reflect over questions which helped them to give more meaningful answers. In all there were 10 close ended items and 6 open-ended items making a total of 16 items

The Mann-Whitney $U$ test analysis, mean, and standard deviations were used to analyse data for the Research Question, which sought to find out whether the CLA improved the performance of the trainees in Integrated Science or not. It also helped to determine whether there was any significant difference between the performance of the trainees in both the control and the experimental groups.

\section{Results and Discussion}

The Research Question sought to find out the performance of trainees in some selected topics in Integrated Science after they had been taught for some weeks using the CLA. To answer this research question, two groups of the trainees (that is the control and the experimental groups) were first given pretest items to respond to. The purpose was to find out whether there was any difference between the control and the experimental groups prior to the intervention stage of the study. The results of the mean performances of the trainees from the two groups in the pretest are presented in Table 1.

Table 1: Mean Performances of Trainees from the Control and Experimental Groups in the Pretest

\begin{tabular}{|l|l|l|l|c|}
\hline Group & N & M & SD & Max score \\
\hline Control & 40 & 13.5 & 7.8 & 31 \\
\hline Experimental & 40 & 11.5 & 7.7 & 31 \\
\hline
\end{tabular}

From Table 1, with a mean of 13.5 ( $\mathrm{SD}=7.8$, Max score $=31$ ), two-thirds of the trainees in the control group could be said to be found between the range of 5.7 and 21.3. The mean for the trainees in the experimental group was calculated as 11.5 ( $\mathrm{SD}=7.7$, Max score $=31)$. This gave an indication that twothirds of the trainees in the experimental group could be found within the range of 3.8 to 19.2. The findings in Table 1 show that there was a difference between the performances of the trainees from both the control and the experimental groups at the beginning of the study. To find out whether the difference was statistically significant, the performances of the trainees from the control and the experimental groups were therefore subjected to Mann-Whitney U test analysis. The Mann-Whitney U test analysis was used because, in the first place, intact classes were used. Secondly, when the distribution of the scores from the pretest was tested using the Kolmogorov-Smirnov test, the value, 0.000 was calculated for both the control and the experimental groups. The calculated value of 0.000 was lower than the significant value of 0.05 , which gave an indication that the normality of the distribution of the trainees' scores on the pretest has been violated and therefore the independent-samples t-test cannot be used to test for the difference. The results of the MannWhitney $\mathrm{U}$ test analysis are presented in Table 2.

Table 2: Results of the Mann-Whitney U Test of the Control and Experimental Groups on Trainees' Performances in the Pretest

\begin{tabular}{|l|l|l|l|l|}
\hline Group & $\mathbf{N}$ & Mean rank & $\mathbf{Z}$ & p-value \\
\hline
\end{tabular}




\begin{tabular}{|l|l|l|l|l|} 
Control & 40 & 43.1 & -1 & $0.306^{*}$ \\
\hline Experimental & 40 & 37.9 & & \\
\hline
\end{tabular}

* Not significant, $\mathrm{p}>0.05$

The results in Table 2 show that there was no statistical significant difference between the performance of the trainees from the control and experimental groups in the pretest. This is because the mean rank, 43.1 (Mann-Whitney $\mathrm{U}=694.5, \mathrm{Z}=-1.0, \mathrm{p}=0.306$ ) of the trainees from the control group was not statistically significantly different from the mean rank, 37.9 of the trainees from the experimental group in the pretest on some selected topics in Integrated Science. This means that the trainees from both the control and the experimental groups were of the same performance prior to the intervention stage of the study.

The Research Question 1 further sought to find out the performances of the teacher trainees in a posttest on some selected topics in Integrated Science after the intervention (that is CLA) has been administered to the experimental group. Table 3 presents the results on the mean performances of the trainees from the control and the experimental groups in the posttest.

Table 3: Mean Performances of Trainees from the Control and Experimental Groups in the Posttest

\begin{tabular}{|l|l|l|l|l|}
\hline Group & N & M & SD & Max score \\
\hline Control & 40 & 15 & 8.9 & 42 \\
\hline Experimental & 40 & 35.4 & 9.3 & 49 \\
\hline
\end{tabular}

From Table 3, with mean of 15.0 ( $\mathrm{SD}=8.9$, Max score $=42$ ), almost two-thirds of the trainees from the control group could be said to be found in the range of 6.1 to 23.9. For the experimental group, it could be seen from Table 3 that with a high mean of $35.4(\mathrm{SD}=9.3$, Max score $=49)$, about two-thirds of the trainees scored marks in the range of 26.1 to 44.7 in the posttest. The findings from Table 3 show that there was difference in the mean performances between the trainees from the control group and that of the experimental group. The Mann-Whitney $U$ test analysis was therefore used to find out whether the difference was statistically significant. Table 4 presents the results of the Mann-Whitney U test analysis on the posttest scores of the trainees from both the control and the experimental groups.

The results in Table 4 show that there was statistically significant difference between the performance of the trainees from the control and experimental groups in the posttest. This is because the mean rank (mean rank $=23.0$, Mann-Whitney $\mathrm{U}=99.0, \mathrm{Z}=-6.8, \mathrm{p}=0.000$ ) of the trainees from the control group was less than the mean rank, 58.0 of the trainees from the experimental group in the posttest on some selected topics in Integrated Science.

Table 4: Results of the Mann-Whitney U Test of the Control and Experimental Groups on Trainees' Performances in the Posttest

\begin{tabular}{|l|c|l|l|l|}
\hline Group & $\mathbf{N}$ & Mean rank & $\mathbf{Z}$ & p-value \\
\hline Control & 40 & 23 & -6.8 & $0.000^{*}$ \\
\hline Experimental & 40 & 58 & & \\
\hline
\end{tabular}

* Significant, $\mathrm{p}<0.05$

The findings from Table 4 show that the trainees from the experimental group performed better in the posttest than their counterparts from the control group. This shows that the performance of the trainees in the experimental group was enhanced after they had been taught using the CLA, and hence the intervention had a positive impact on the trainees' performance in the selected topics in Integrated Science.

\section{Conclusions}

The study has revealed that the Cooperative Learning Approach helped the trainees involved in the study to improve on their performance in Integrated Science. This is because the performance of the experimental group improved significantly compared to the control group after the intervention. This confirms the findings of Becker and Watts (1995); Effandi (2003); and Lee (1999), which show that students who were 
found in small cooperative groups performed better than their counterparts who were allowed to study individually or were lectured.

\section{References}

[1.] Aggrey, S. (1993). Promotion of Self-Employment in Vocational and Technical Institutions in Ghana. Accra: Cita Printing Press.

[2.] Antwi, M. K. (1992). Education, Society and Development in Ghana. Accra: Unimax Publishers Limited.

[3.] Becker, W. E., \& Watts, M. (1995). Teaching Tools: Teaching Methods in Undergraduate Economics. Economics Inquiry, 33, 692-700.

[4.] Effandi, Z. (2003) Cooperative Learning for Science Teaching. Kuala Lumpur: Kebangsaan University Press.

[5.] Hallack, J. (1990). Investing in the Future Setting. Educational Priorities in Developing World. Paris: 11EP-UNESCO.

[6.] Institute of Education. (2005). Chief Examiner's Report, Integrated Science 1. Diploma in Basic Education. Cape Coast: University of Cape Coast.

[7.] Institute of Education. (2006). Chief Examiner's Report, Integrated Science 1. Diploma in Basic Education. Cape Coast: University of Cape Coast.

[8.] Institute of Education. (2007). Chief Examiner's Report, Integrated Science 1. Diploma in Basic Education. Cape Coast: University of Cape Coast.

[9.] Institute of Education. (2008). Chief Examiner's Report, Integrated Science 1. Diploma in Basic Education. Cape Coast: University of Cape Coast.

[10.] Institute of Education. (2009). Chief Examiner's Report, Integrated Science 1. Diploma in Basic Education. Cape Coast: University of Cape Coast.

[11.] Institute of Education. (2010). Chief Examiner's Report, Integrated Science 1. Diploma in Basic Education. Cape Coast: University of Cape Coast.

[12.] Lee, G. E. (1999). Cooperative Learning for Learners. New York: Randon House.

[13.] Shaughnessy, N. (1992). Cooperative Student Activities as Learning Devices. Boston: Beacon Press.

[14.] Singer, H. W. (1964). International Development: Growth and Change. New York: McGraw-Hill.

[15.] UNESCO. (1986). Source Book for Science Teaching. Paris: UNESCO.

[16.] Watts, M., \& Moore, R. L. (1998). Teaching Introductory Economics with a Collaborative Learning Laboratory Component. Journal of Economics Education, 29(4), 321-330. 